\section{Evaluation of Low-maintenance Landscape Roses in Central Florida}

\author{
Jozer Mangandi ${ }^{1,3}$, Sydney Park Brown ${ }^{1,4,5}$, and Natalia Peres ${ }^{2,4}$
}

\begin{abstract}
ADDITIONAL INDEX WORDs. old garden roses, black spot, Cercospora rosicola, cercospora leaf spot, chilli thrips, Diplocarpon rosae, modern roses, Rosa sp., Scirtothrips dorsalis
\end{abstract}

\begin{abstract}
SUMmaRY. Environmental conditions in Florida are favorable for the development and persistence of insects and diseases that affect rose (Rosa sp.) plants, necessitating periodic applications of pesticides to maintain plant appearance. In addition, nutrient-deficient and well-drained soils in Florida force gardeners to provide supplemental fertilizer and water. Landscape performance is rarely considered for the development of new rose cultivars; consequently, careful selection of cultivars adapted to local conditions is necessary to reduce maintenance. The objective of this study was to develop recommendations of own-root, low-maintenance roses among 11 old garden and modern cultivars for central Florida. Plants were provided with minimal amounts of water and fertilizer, no control for diseases and insects, and no grooming or deadheading. Weekly evaluations were performed on all plants for plant quality, flower coverage; and incidence of black spot (caused by Diplocarpon rosae), cercospora leaf spot (caused by Cercospora rosicola), and foliar damage [caused by chilli thrips (Scirtothrips dorsalis)]. Damage caused by the foliar diseases and chilli thrips were the major factors that affected plant quality, vigor, and subsequently, flower production. Differences in susceptibility to these three factors were found among cultivars, enabling the classification of the 11 cultivars as recommended, cautiously recommended, and not recommended for central Florida. After two years, 'Mrs. B.R. Cant' appeared to be the most suited for central Florida as plant quality and flower production were fairly constant. 'Duchesse de Brabant', 'RADrazz' (Knock Out ${ }^{\circledR}$ ), and 'Spice' were the next best performers and are cautiously recommended for central Florida. These cultivars were minimally affected by both diseases, showing low severity of yellowing and defoliation nor a decline in flower production. "Bailey Red", 'Old Blush', 'Belinda's Dream', 'Perle d'Or', 'BUCbi' (Carefree Beauty ${ }^{\mathrm{TM}}$ ), 'Mutabilis', and 'WEKcisbako' (Home Run ${ }^{\circledR}$ ) had severe defoliation, poor growth, and low vigor in this study and do not appear to be low-maintenance landscape roses for central Florida.
\end{abstract}

$\mathrm{R}$ oses are one of the most popular plants in the horticulture industry, featuring a variety of plant forms, flower forms, colors, and scents that make them versatile landscape plants. Even though cultivar development has made rose cultivation possible around the world, growing roses in Florida can be difficult. Plant performance is diminished by the use of both cultivars and rootstocks unadapted to Florida's climate and soils, as well as inadequate irrigation and fertilization (Manners, 1999). Moreover, mobile nutrients are easily leached

\footnotetext{
Trade names and products are mentioned without endorsement or discrimination.

${ }^{1}$ Department of Environmental Horticulture, Gulf Coast Research and Education Center, University of Florida, 1200 N Park Road, Plant City, FL 33563

${ }^{2}$ Department of Plant Pathology, Gulf Coast Research and Education Center, University of Florida, 14625 County Road 672, Wimauma, FL 33598

${ }^{3}$ Research Assistant.

${ }^{4}$ Associate Professor.
}

${ }^{5}$ Corresponding author. E-mail: spbrown@ufl.edu. from Florida's sandy soils by characteristically heavy rains (Kottek et al., 2006; Simonne and Hochmuth, 2010). In addition, the subtropical climate of the region is favorable for the development of diseases, insects, and other pests to which roses are susceptible.

Foliar diseases caused by fungi are predominant and one of the limiting factors for growing roses in Florida (Miller, 1961). Although cultural practices can help reduce or eliminate the need for chemical control (Mueller et al., 2008), in Florida, fungicide applications may be necessary. Roses are also susceptible to a wide range of arthropods that can cause direct damage or are vectors of diseases, such as mites (Acaridae), thrips (Thysanoptera), aphids (Aphididae), beetles (Coleoptera), and leaf cutter bees (Megachile sp.) (Horst and Cloyd, 2007). Also, nematodes (Nematoda) cause severe damage to the roots of roses by interfering with water and nutrient absorption, ultimately decreasing plant vigor and flower production (Knox et al., 2008). Chemical control may not be effective or possible for some of these pests, and cultural practices such as release of natural enemies and removal of infested tissues are often recommended. Plant performance and appearance suffer as these pests often produce severe tissue damage, defoliation, and subsequent plant death. Grafting roses into 'Double Cherokee' (Rosa xfortuniana) rootstock has shown to improve tolerance to nematodes and enhance plant vigor, flower production, and longevity on roses grown in Florida's soils (Manners, 1999). However, own-root plants were used in this study so that cultivars that proved worthy of recommendation could be easily propagated by the nursery industry.

Roses are classified into two major groups: old garden (OGR), defined as horticultural classes and cultivars present before 1867; and modern roses (MR) which are the horticultural classes and cultivars developed after 1867. Numerous cultivars of OGR perform well in Florida on their own roots (Manners, 1999). However, most of the roses grown in U.S. gardens belong to MR and are typically grafted. Modern roses, specifically those of the horticultural class of hybrid teas, need rigorous pruning in addition to frequent applications of pesticides, fertilizers, and irrigation (Mackay et al., 2008). Moreover, the long growing season in Florida demands grooming, deadheading, and pruning on a regular basis. Low-maintenance roses have gained recent popularity because of the perceived negative impacts pesticides

\begin{tabular}{llll}
\hline $\begin{array}{l}\text { Units } \\
\begin{array}{l}\text { To convert U.S. to SI, } \\
\text { multiply by }\end{array}\end{array}$ & U.S. unit & SI unit & $\begin{array}{l}\text { To convert SI to U.S., } \\
\text { multiply by }\end{array}$ \\
\hline 0.3048 & $\mathrm{ft}$ & $\mathrm{m}$ & 3.2808 \\
3.7854 & $\mathrm{gal}$ & $\mathrm{L}$ & 0.2642 \\
2.54 & inch(es) & $\mathrm{cm}$ & 0.3937 \\
0.4536 & $\mathrm{lb}$ & $\mathrm{kg}$ & 2.2046 \\
28.3495 & $\mathrm{oz}$ & $\mathrm{g}$ & 0.0353
\end{tabular}


and synthetic fertilizers have on the environment and human health (Zlesak, 2007). In addition, governmental restrictions on landscape irrigation have also increased (Mackay et al., 2008). Growing roses in Florida can be successful without these maintenance practices by selecting vigorous and disease resistant or tolerant cultivars. The purpose of our study was to develop recommendations of shrub roses for landscape use in central Florida that can perform well under low maintenance.

\section{Materials and methods}

This study was conducted at the University of Florida Plant City Campus (U.S. Department of Agriculture cold hardiness zone 9a, American Horticultural Society heat hardiness zone 8) from Feb. 2008 to Jan. 2010. Six bare-root plants of the following cultivars were installed on 23 Jan. 2008: Belinda's Dream, BUCbi (Carefree Beauty $^{\mathrm{TM}}$ ), Duchesse de Brabant, WEKcisbako (Home Run ${ }^{\circledR}$ ), RADrazz (Knock Out $\left.^{\circledR}\right)$, Mrs. B.R. Cant, Mutabilis, Old Blush, Perle d'Or, Spice, and "Bailey Red" (it should be noted that some rose authorities now believe "Bailey Red" is actually "Karen Poulsen', but we have assigned the first name for the purpose of this study). These cultivars were selected because they have been deemed low-maintenance roses by Florida gardeners, the Texas Earth-Kind ${ }^{\circledR}$ program (Harp et al., 2009 ) or both. The experimental design was a randomized complete block with two plants per plot in three replications. The Seffner fine sand soil was previously amended with composted cow manure (Black Gold Compost Co., Oxford, FL) at a rate of $50 \mathrm{lb}$ every $1.5 \mathrm{ft}$ along planting beds. Soil $\mathrm{pH}$ was 7.7 after amendments. The compost was applied 3 inches thick in a 2 -ft-wide central band and then incorporated into the upper 6 inches of soil. Plants were placed $8 \mathrm{ft}$ apart on 8 -ft-wide beds covered with ground cloth topped with a 4 -inch layer of fine ground pine bark mulch. The irrigation regime included an establishment period providing water by drip emitters (two per plant) at a rate of 0.5 gal per plant every day for the first 2 weeks and gradually decreasing to every other day for the next two months and once per week for the following 3.5 months. During the maintenance period, $0.5 \mathrm{gal}$ was provided twice per week from October to May and once per week from June to September. Top-dress applications of $15 \mathrm{~N}-3.9 \mathrm{P}-10 \mathrm{~K}$ controlled-release fertilizer (Osmocote Plus 15-9-12; Everris International, Geldermalsen, The Netherlands) were performed as follows: three applications in 2008 on 27 Mar., 9 June, and 8 Sept. at $\approx 4.5,7.0$, and $11.7 \mathrm{~g} /$ plant, respectively. During the second year, fertilizer amounts were increased in proportion to plant growth and $\approx 23.0$ $\mathrm{g} /$ plant were applied on 28 Feb. and 25 July. No pesticide applications or regular grooming was done except for one major pruning on $25 \mathrm{Feb}$. 2009 when the plant canopy was reduced by one-third.

Incidence of black spot, cercospora leaf spot, and foliar damage caused by chilli thrips (Fig. IA-C) was assessed as these affected plant vigor and caused a decline in flower production in many cultivars. Assessments to quantify damage by these pests were conducted on all cultivars twice a month from Sept. 2008 to Apr. 2009 and weekly from June 2009 to Dec. 2009. A scale from 0 to 5 was used to determine the percentage of foliage with black spot and cercospora leaf spot symptoms where $0=$ no symptoms, $1=1 \%$ to $20 \%, 2=21 \%$ to $40 \%, 3=41 \%$ to $60 \%, 4=61 \%$ to $80 \%$, and $5=81 \%$ to $100 \%$ of symptomatic leaves (Moyer et al., 2008). A similar scale was used to evaluate the percentage of foliar curling, bronzing, or both, caused by chilli thrips feeding damage. Flower coverage was assessed as the percent of canopy covered by flowers using a scale from 1 to 5 where $1=0 \%$ (no flowers present), $2=1 \%$ to $25 \%, 3=26 \%$ to $50 \%, 4=51 \%$ to $75 \%$, and $5=76 \%$ to $100 \%$ flower canopy coverage (Wilson and Knox, 2006). A similar scale (1-5) was used to measure overall visual plant quality as follows: $1=$ very poor quality, plants not acceptable, severe leaf necrosis or yellowing; 2 = poor quality, not acceptable, large areas of necrosis or yellowing, poor form; 3 = fair quality, marginally acceptable, somewhat desirable form and color; 4 = good quality, very acceptable, nice color, good form, desirable; and 5 = excellent quality, very desirable landscape performance (Wilson and Knox, 2006). Weekly evaluations of plant quality and flower coverage were conducted for all cultivars from Mar. 2008 to Feb. 2009 and from Mar. 2009 to Jan. 2010 for 84 weeks total.

Plant quality and flower coverage were considered categorical variables and thus, were analyzed using Fisher's exact test each week separately. This test allows detecting statistical differences on the rating value's frequencies for each variable among cultivars. Statistical comparisons between cultivars and plant quality and flower coverage were obtained with the FREQ procedure in SAS (version 9.2; SAS Institute, Cary, NC). Disease severity ratings for both diseases were analyzed by obtaining the area under the disease progress curve (AUDPC) according to Madden and Campbell (1990) for an interval of 67 weeks. AUDPC values were analyzed with the SAS MIXED procedure and differences among cultivars were compared using orthogonal contrasts and determined significant at $P \leq 0.05$. The Pearson correlation coefficient between AUDPC values for black spot and cercospora leaf spot was calculated using the SAS CORR procedure. A damage severity index (DSI) was calculated to analyze chilli thrips foliar
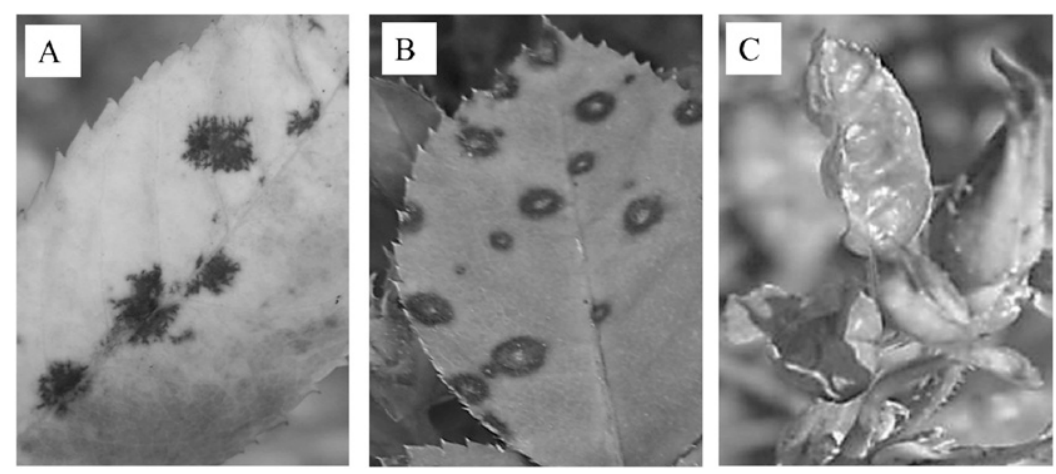

Fig. 1. (A) Typical symptoms of black spot, (B) cercospora leaf spot, and (C) leaf deformation caused by chilli thrips on rose leaves. 
damage to the rose plants. The index was calculated for each plant and was obtained by multiplying the number of times each plant was evaluated as symptomatic by its corresponding number on the damage scale (within 1 to 5 , rating of zero is not included since that indicated healthy plants) for 57 weeks total. The result was then divided by the total number of times a plant was rated as damaged. The formula can be summarized as DSI $=\left\{\left[\sum\left(\right.\right.\right.$ frequency $_{1} \times$ rating $\left._{\text {value }}\right)+$ frequency $_{n} \times$ rating $_{\left.\left.\text {value }_{n}\right)\right] \div} \div$ (total number of symptomatic readings)\}. The damage severity index was subjected to an analysis of variance using the ANOVA procedure in SAS. Tukey's test was used to compare differences among DSI means (at $P \leq 0.05)$.

\section{Results and discussion}

This study evaluated the performance of 11 own-root OGR and MR shrub rose cultivars grown in central Florida with minimal inputs. Cultivars were grouped according to their overall performance as recommended, cautiously recommended, and not recommended. Rating frequencies for flower coverage and plant quality for the cultivars Mrs. B.R. Cant, Spice, and Belinda's Dream are shown in Fig. 2A-F and are characteristic for the three groups (a complete list of the flower coverage and plant quality ratings for the 11 cultivars can be found in Supplemental Fig. 1). Flower coverage and plant quality data were analyzed each week to explore the statistical differences among cultivars in different weeks. Significant differences among cultivars occurred in 60 weeks for flower coverage and in 80 weeks for plant quality (data not shown). During 2008-09, differences in flower coverage among cultivars
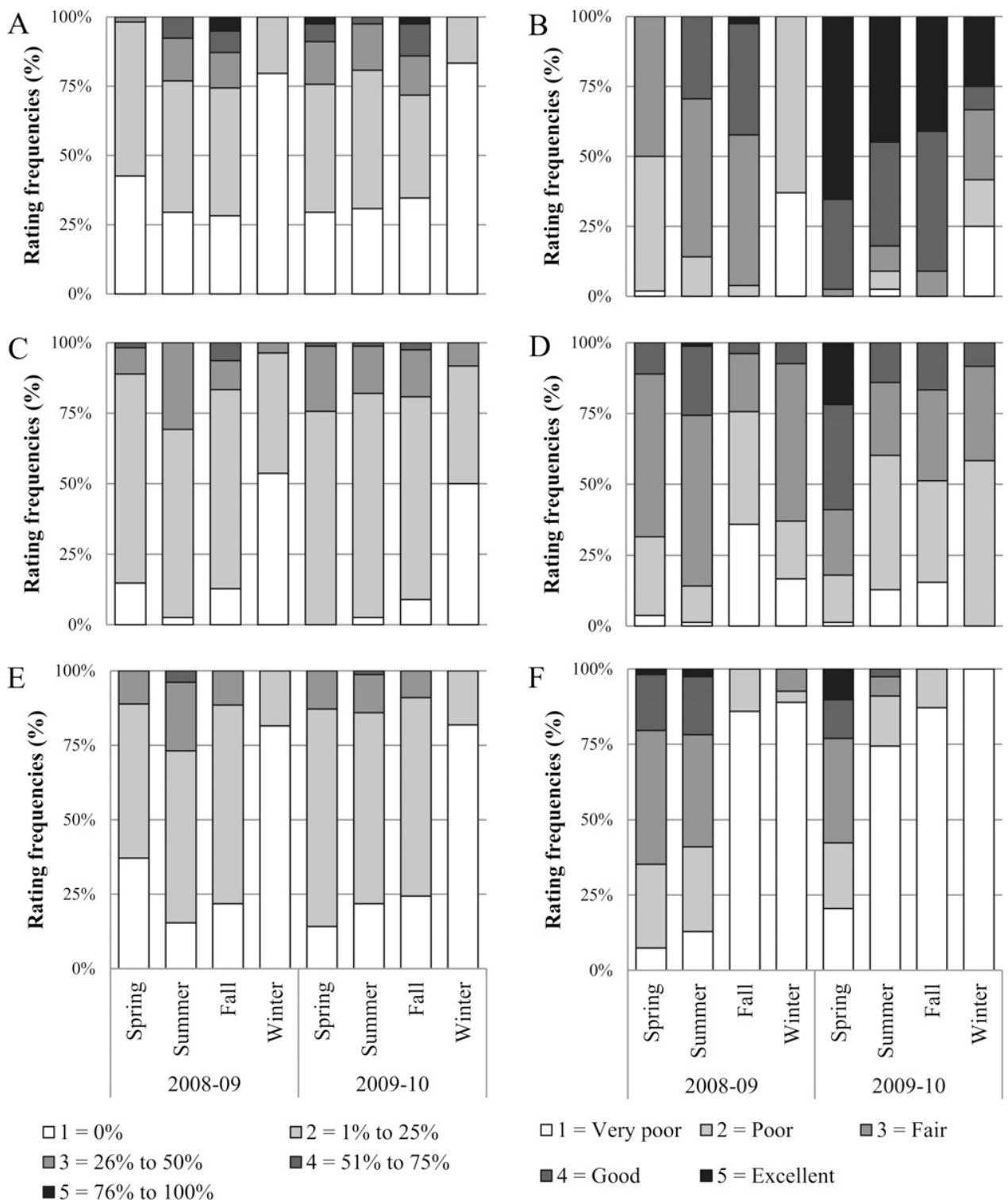

Fig. 2. Seasonal frequency of flower coverage (A, C, and E) and plant quality (B, D, and F) ratings of rose cultivars Mrs. B.R. Cant (top), Spice (middle), and Belinda's Dream (bottom). Seasons are distributed as follow: Spring (21 Mar. to 20 June), Summer (21 June to 22 Sept.), Fall (23 Sept. to 20 Dec.), and Winter $(21$ Dec. to 20 Mar.). Cultivars were categorized according to their overall performance as recommended for Florida (Mrs. B.R. Cant), cautiously recommended [Spice, Duchesse de Brabant, and RADrazz (Knock Out ${ }^{\circledR}$ )], and not recommended [Belinda's Dream, "Bailey Red", Old Blush, Perle d'Or, BUCbi $\left(\right.$ Carefree Beauty $^{\mathrm{TM}}$ ), WEKcisbako (Home Run ${ }^{\circledR}$ ), and Mutabilis]. 
were significant in 26 weeks, whereas differences in flower coverage were significant in 34 weeks during 200910. Fewer differences were observed during 2008-09 because of lack of full establishment and little expression of flowering traits until 2009-10.

All cultivars were repeat-flowering roses, but individual flowering characteristics of the class or cultivar also affected flower coverage ratings (Fig. 2A, $\mathrm{C}, \mathrm{E}$ ). For instance, MR were specifically bred and selected for increased flower display in the garden (Marriott, 2003); thus, 'Belinda's Dream', 'RADrazz' (Knock Out ${ }^{\circledR}$ ), 'BUCbi' (Carefree Beauty ${ }^{\mathrm{TM}}$ ), 'WEKcisbako' (Home Run ${ }^{\circledR}$ ), and 'Perle d'Or' are well known for producing large clusters of flowers. However, with the exception of 'RADrazz' (Knock Out $\left.{ }^{\circledR}\right)$, these cultivars frequently received low flower coverage ratings (two or less) in our evaluation. Similarly, all OGR in this study characteristically produce flowers in clusters and coverage ratings were, in general, similar to those of the MR with the exception of 'Mrs. B.R. Cant'. Both 'Mrs. B.R. Cant' (Fig. 2A) and 'RADrazz' (Knock Out ${ }^{\circledR}$ ) received flower coverage ratings of $75 \%$ or higher. The cultivars Spice (Fig. 2C) and Duchesse de Brabant had continuous flower coverage between $1 \%$ and $50 \%$, but occasionally higher than $50 \%$. Poor flowering cultivars such as Belinda's Dream (Fig. 2E), "Bailey Red", Old Blush, Perle d'Or, WEKcisbako (Home Run ${ }^{\circledR}$ ), Mutabilis, and BUCbi (Carefree Beauty ${ }^{\mathrm{TM}}$ ) had $25 \%$ or less flower coverage over $75 \%$ of the time. All cultivars showed decreased flowering during winter in both periods. Flower coverage could be influenced by plant vigor, particularly on own-root plants. None of our cultivars were grafted, thus in addition to pest pressure, this possibly contributed to a reduction in plant vigor and flower production. As previously mentioned, roses grafted onto 'Double Cherokee' perform better on Florida's soils. However, grafting increases labor and costs in the nursery; therefore, selecting good performing own-root, low-maintenance roses could promote commercial production of such cultivars.

Cultivars showed significant differences in plant quality from the beginning of the evaluation as the plants came from different sources and were of different sizes. A general improvement of quality was observed in all cultivars in the first months of evaluation; however, various factors soon began to affect plant appearance. This trend can be observed on the plant quality ratings for our cultivar examples as these changed through the seasons (Fig. 2B, D, F). Cultivars of OGR occasionally produced sprawling canes, which downgraded their appearance, whereas cultivars of MR generally had neat, compact forms. Black spot, cercospora leaf spot, and chilli thrips were responsible, to a lesser or greater degree depending on cultivar, for defoliation and reduced plant growth and vigor resulting in poor plant quality. Only 'Mrs. B.R. Cant' (Fig. 2B) showed an outstanding improvement in plant quality after the first year. This cultivar received good to excellent plant quality ratings consistently during 2009-10. 'Spice' (Fig. 2D), 'Duchesse de Brabant', and 'RADrazz' (Knock Out ${ }^{\circledR}$ ) were rated as fair to good quality at least $50 \%$ of the time. 'Belinda's Dream' (Fig. 2F), "Bailey Red", 'Old Blush', 'Perle d'Or', 'WEKcisbako' (Home Run $^{\circledR}$ ), 'BUCbi' (Carefree Beauty ${ }^{\top \mathrm{M}}$ ), and 'Mutabilis' were rated as very poor to poor for most of both periods.

AUDPC values for disease severity were significantly different among the 11 cultivars for both diseases (Table 1). Cultivars with low AUDPC values for each disease were considered resistant when compared with the other cultivars, whereas those with the highest values were considered susceptible. Lowest black spot AUDPC values were observed for the MR 'WEKcisbako'
(Home Run ${ }^{\circledR}$ ) and 'RADrazz' (Knock Out $\left.^{\circledR}\right)($ Table 1$)$, which were regarded as more resistant than the other cultivars. 'RADrazz' (Knock Out ${ }^{\circledR}$ ) has been previously reported showing low levels of defoliation because of black spot in north-central Texas under minimal inputs (Mackay et al., 2008). In addition, resistance to black spot and cercospora leaf spot on 'RADrazz' $\left(\right.$ Knock Out $\left.{ }^{\circledR}\right)$ has been reported also in Tennessee, MS (Mynes et al., 2007, 2009), and Alabama (Hagan and Arkidge, 2010). Even though yellowing and defoliation in the Knock Out ${ }^{\circledR}$ series has been attributed to an unknown disorder (Hagan and Arkidge 2009), cercospora leaf spot was continuously observed in 'RADrazz' $\left(\right.$ Knock Out $\left.{ }^{\circledR}\right)$ in our study. However, all plants of this cultivar retained most of their foliage year-round with no yellowing present. It is possible that the foliage density of 'RADrazz' $\left(\right.$ Knock Out $\left.^{\circledR}\right)$ could have contributed to the persistence of cercospora leaf spot on this cultivar. 'WEKcisbako' $\left(\right.$ Home Run ${ }^{\circledR}$ ) was selected from a cross involving 'RADrazz' (Knock Out $^{\circledR}$ ) as the pollen donor (Weeks Roses, 2010), which suggests that the high level of resistance to black spot could have come from this parent. The OGR 'Mutabilis' was the most susceptible to black spot. For cercospora leaf spot, the lowest AUDPC values were found for the OGR 'Old Blush' (Table 1), which was significantly more resistant than the other cultivars. The most susceptible cultivar was the MR 'WEKcisbako' (Home Run $\left.^{\circledR}\right)$.

Table 1. Mean values of the area under the disease progress curve (AUDPC) for the severity of black spot and cercospora leaf spot in 11 cultivars of old garden (OGR) and modern (MR) roses in central Florida from Sept. 2008 to Dec. 2009.

\begin{tabular}{|c|c|c|c|}
\hline Cultivar $^{\mathrm{z}}$ & Group & $\frac{\text { Black spot }}{\text { AUDPC }^{y}}$ & $\frac{\text { Cercospora leaf spot }}{\text { AUDPC }}$ \\
\hline WEKcisbako (Home Run ${ }^{\circledR}$ ) & MR & $14 \mathrm{a}^{\mathrm{x}}$ & $1819 \mathrm{~h}$ \\
\hline RADrazz $\left(\right.$ Knock Out $\left.{ }^{\circledR}\right)$ & MR & $19 \mathrm{a}$ & $1429 \mathrm{e}$ \\
\hline Perle d'Or & MR & $100 \mathrm{~b}$ & $1482 \mathrm{fg}$ \\
\hline BUCbi (Carefree Beauty ${ }^{\mathrm{TM}}$ ) & MR & $186 \mathrm{~b}$ & $1618 \mathrm{~g}$ \\
\hline Mrs. B.R. Cant & OGR & $828 \mathrm{c}$ & $138 \mathrm{c}$ \\
\hline Spice & OGR & $866 \mathrm{~cd}$ & $210 \mathrm{~d}$ \\
\hline Duchesse de Brabant & OGR & $919 \mathrm{~d}$ & $1552 \mathrm{~g}$ \\
\hline Belinda’s Dream & MR & $1029 \mathrm{e}$ & $194 \mathrm{~d}$ \\
\hline Old Blush & OGR & $1149 \mathrm{f}$ & $36 \mathrm{a}$ \\
\hline "Bailey Red" & OGR & $1251 \mathrm{~g}$ & $137 \mathrm{c}$ \\
\hline Mutabilis & OGR & $2172 \mathrm{~h}$ & $57 \mathrm{~b}$ \\
\hline
\end{tabular}

${ }^{\text {zT} T r a d e ~ n a m e ~ i n ~ p a r e n t h e s i s . ~}$

${ }_{\text {yAUDPC }}=\Sigma\left\{\left[\left(\right.\right.\right.$ rating $_{1}+$ rating $\left.\left._{2}\right) \div 2\right] \times\left(\right.$ difference of days between rating $_{2}$ and rating $\left.\left._{1}\right)\right\}$ for a total period of 67 weeks.

${ }^{x}$ Means followed by the same letters are not significantly different $(P \leq 0.05)$ according to orthogonal contrasts. 
Manners (1999) noted that horticultural classes of MR are generally more susceptible to black spot than those of OGR. In contrast, we found that most of the MR cultivars in our study were significantly more resistant to black spot than the OGR (Table 1). The exception was 'Belinda's Dream'. Although previously reported as resistant (Manners, 1999), it was susceptible to black spot in our evaluation. Manners (1999) reported that OGR 'Mrs. B.R. Cant', 'Duchesse de Brabant', and 'Mutabilis' were resistant to black spot, but these cultivars were susceptible in our evaluation. There are more than 20,000 rose cultivars registered worldwide, thus neither Manners' cultivar list nor ours are totally representative of any particular group. Hence, it is important to remark that evaluating cultivars for suitability in specific areas is significant. Differences to black spot susceptibility among the cultivars screened in this study compared with previous reports might be explained by the occurrence of races of the fungus as previously documented (Wenefrida and Spencer, 1993; Whitaker et al., 2007; Yokoya et al., 2000). In addition, Whitaker et al. (2007) indicated that genetic variation of black spot pathogen can be found even within isolates of the same race, although races and specific geographical locations might not be significantly associated. The rose cultivars used in our trial were obtained from nurseries located in three different states (California, Alabama, and Texas) presenting the possibility that the plants were previously infected by pathogenic races at those sites other than those already present in central Florida. Individual cultivar characteristics might have also contributed to susceptibility levels. 'Mrs. B.R. Cant' has a large, open canopy and did not produce regular flushes of new foliage. These characteristics might have reduced the probability of continuous infection compared with cultivars with denser canopies (such as 'Mutabilis') that may retain humidity and inoculum for longer periods. Cercospora leaf spot on roses has been regarded nationwide as less important than black spot and thus, information is lacking on the epidemiology of this disease. Although some cultivars have been screened for tolerance to cercospora leaf spot, possible resistance mechanisms in rose cultivars have not been established.
Previous studies reported that cultivars highly susceptible to black spot show more resistance to cercospora leaf spot and vice versa (Mynes et al., 2007). We observed a similar tendency as highly resistant cultivars to black spot such as 'RADrazz' (Knock Out $\left.{ }^{\circledR}\right)$ and 'WEKcisbako' (Home Run ${ }^{\circledR}$ ) were also among the most susceptible to cercospora leaf spot as shown by the AUDPC. The opposite was also noted as 'Old Blush' and 'Mutabilis', two OGR cercospora leaf spot-resistant cultivars, were among the most susceptible to black spot. Evaluating the AUDPC values, we obtained a Pearson correlation coefficient $(-0.77, P<$ 0.001 ) suggesting a significant negative relationship between susceptibility to black spot and cercospora leaf spot within the cultivars in our study.

Chilli thrips were reported first in Florida in 2005 on Knock Out ${ }^{\circledR}$ roses but were considered established as a pest in 2007 (Hodges et al., 2005; Ludwig and Bográn, 2007). Rose cultivars have not yet been evaluated for tolerance to this new pest. Although typical damage from chilli thrips was observed on all cultivars during our evaluation, mean values of damage severity (measured by the DSI) were significantly different among rose cultivars (Table 2). 'Mrs. B.R. Cant' had the lowest DSI, but it was not different from 'Old Blush' and "Bailey Red". The remaining three OGR were the most susceptible to the feeding injury: 'Spice', 'Duchesse de Brabant', and 'Mutabilis' had the highest DSI values. Chilli thrips cause damage principally

Table 2. Mean values of the damage severity index (DSI) caused by chilli thrips in 11 cultivars of old garden (OGR) and modern (MR) roses in central Florida from Sept. 2008 to Dec. 2009.

\begin{tabular}{|c|c|c|}
\hline Cultivar $^{\mathrm{z}}$ & Group & $\frac{\text { Chilli thrips damage }}{\text { DSI }^{\mathrm{y}}}$ \\
\hline Mrs. B.R. Cant & OGR & $1.01 \mathrm{a}^{\mathrm{x}}$ \\
\hline Old Blush & OGR & $1.24 \mathrm{ab}$ \\
\hline "Bailey Red" & OGR & $1.30 \mathrm{ab}$ \\
\hline Belinda's Dream & MR & $1.59 \mathrm{bc}$ \\
\hline BUCbi (Carefree Beauty ${ }^{\top \mathrm{M}}$ ) & MR & $1.59 \mathrm{bc}$ \\
\hline Perle d'Or & MR & $1.61 \mathrm{bc}$ \\
\hline RADrazz (Knock Out $\left.{ }^{\circledR}\right)$ & MR & $1.78 \mathrm{~cd}$ \\
\hline WEKcisbako (Home Run ${ }^{\circledR}$ ) & MR & $1.85 \mathrm{~cd}$ \\
\hline Spice & OGR & $2.14 \mathrm{~d}$ \\
\hline Duchesse de Brabant & OGR & $2.86 \mathrm{e}$ \\
\hline Mutabilis & OGR & $3.69 \mathrm{f}$ \\
\hline
\end{tabular}

${ }^{\mathrm{z}}$ Trade name in parenthesis.

${ }^{y} \mathrm{DSI}=\sum\left[\left(\right.\right.$ frequency $_{1} \times$ rating $\left._{\text {value }}\right)+\left(\right.$ frequency $_{n} \times$ rating value $\left.\left._{n}\right)\right] \div($ total of symptomatic readings $)$ for a total period of 57 weeks.

${ }^{x}$ Mean values followed by the same letters are not significantly different $(P \leq 0.05)$ according to Tukey's test. on the young leaves and flower buds of their hosts (Seal and Klassen, 2005). It is conceivable that cultivars with abundant and recurrent new foliage might be preferred and, in fact, those cultivars with the highest DSI values also produced new growth continuously. 'Mrs. B.R. Cant', 'Old Blush", and "Bailey Red", which produced less profuse foliage and were more cyclical in their foliage production, had lower DSI values.

Cultivars were grouped according to their overall performance as recommended, cautiously recommended, and not recommended. Two years after establishment, 'Mrs. B.R. Cant' appeared to be the most suited for central Florida. This cultivar had low susceptibility to chilli thrips (Table 2) and was moderately susceptible to black spot and cercospora leaf spot (Table 1). Plant quality of this cultivar improved greatly during the second year of evaluation and flower production was fairly constant (Fig. 1A and B).

'Duchesse de Brabant' and 'RADrazz' (Knock Out ${ }^{\circledR}$ ) were susceptible to cercospora leaf spot but less prone to defoliation than the susceptible cultivars. 'RADrazz' (Knock Out $^{\circledR}$ ) also was moderately susceptible to chilli thrips, whereas 'Duchesse de Brabant' was highly susceptible. Despite these problems, these plants produced well-structured shrubs. Similarly, 'Spice' had an overall fair quality rating, maintained a well-rounded plant structure, and defoliated less even though it was highly susceptible to chilli thrips and moderately susceptible to black 
spot and cercospora leaf spot. Flower production on these three cultivars did not appear to be greatly reduced. Frequencies of plant quality and flower coverage ratings for 'Spice' are shown in Fig. IC and D, which are representative for this group. These cultivars are cautiously recommended as lowmaintenance, own-root cultivars in central Florida, particularly where flower production is valued over foliage appearance.

The OGR "Bailey Red" and 'Old Blush' and the MR 'Belinda's Dream' were highly susceptible to black spot (Table 1). 'Perle d'Or', 'BUCbi' (Carefree Beauty ${ }^{\mathrm{TM}}$ ), and 'WEKcisbako' (Home Run ${ }^{\circledR}$ ), all MR, were highly susceptible to cercospora leaf spot (Table 1). All these cultivars suffered severe defoliation, poor growth, and reduced vigor, consequently failing to form well-structured shrubs. Frequencies of plant quality and flower coverage ratings for 'Belinda's Dream' are shown in Fig. IE and F representing the low performance of cultivars in this group. In addition, 'Perle d'Or', 'WEKcisbako' (Home Run ${ }^{\circledR}$ ), and 'Belinda's Dream' were also prone to dieback. Although plants of these cultivars received high flowering ratings, these were due to the small size of the plant in comparison with the large clusters of flowers produced. 'Mutabilis' was the cultivar most susceptible to chilli thrips damage showing damaged foliage throughout both years. Chilli thrips damage and high susceptibility to black spot resulted in severe defoliation on this cultivar. However, all 'Mutabilis' plants survived and continued to grow, whereas those of 'BUCbi' (Carefree Beauty ${ }^{\mathrm{T} M}$ ), "Bailey Red", 'Perle d'Or', 'WEKcisbako' (Home Run ${ }^{\circledR}$ ), and 'Belinda's Dream' were greatly weakened after the second year and were removed from the trial. Consequently, these cultivars are not recommended as low-maintenance, own-root shrub roses for central Florida.

\section{Literature cited}

Hagan, A.K. and J.R. Arkidge. 2009. Unknown leaf spotting and defoliation of Knock Out roses. Proc. Southern Nursery Assn. Res. Conf. 54:69-74.
Hagan, A.K. and J.R. Arkidge. 2010. Search for the 'no spray' rose continued. Proc. Southern Nursery Assn. Res. Conf. 55:430-435.

Harp, D.A., D. Zlesak, G. Hammond, S George, and W. Mackay. 2009. EarthKind ${ }^{\circledR}$ rose trials: Identifying the world's strongest, most beautiful landscape roses. Floricult. Ornamental Biotechnol. 3:166-175.

Hodges, G., G.B. Edwards, and W. Dixon. 2005. Chilli thrips Scirtothrips dorsalis Hood (Thysanoptera: Thripidae). A new pest thrips for Florida. 30 June 2009. <http://www.doacs.state.fl.us/pi/ enpp/ento/chillithrips.html>.

Horst, R.K. and R.A. Cloyd. 2007. Compendium of rose diseases and pests. 2 nd ed. Amer. Phytopathol. Soc., St. Paul, MN.

Knox, G.W., M. Paret, and R.F. Mizell, III. 2008. Rose pests and diseases in Florida. Univ. Florida. Inst. Food Agr. Sci. ENH 1108.

Kottek, M., J. Grieser, C. Beck, B. Rudolf, and F. Rubel. 2006. World map of the Köppen-Geiger climate classification updated. Meteorologische Zeitschrift 15: 259-263.

Ludwig, S.W. and C. Bográn. 2007. Chilli thrips: A new pest in the home landscape. Texas Coop. Ext. Serv. EEE-00041.

Mackay, W.A., S.W. George, C. McKenney, J.J. Sloan, R.I. Cabrera, J.A. Reinert, P. Colbaugh, L. Lockett, and W. Crow. 2008. Performance of garden roses in northcentral Texas under minimal input conditions. Hort Technology 18:417-422.

Madden, L.V. and C.L. Campbell. 1990. Introduction to plant disease epidemiology. Wiley, New York, NY.

Manners, M.M. 1999. Lower maintenance roses for Florida. Proc. Florida State Hort. Soc. 112:108-110.

Marriott, M. 2003. History of roses in cultivation, Modern (Post 1800), p. 402409. In: A.V. Roberts, T. Debener, and S. Gudin (eds.). Encyclopedia of rose science. Elsevier Academic Press, San Diego, CA.

Miller, H.N. 1961. Control of rose leaf diseases in Florida. Proc. Florida State Hort. Soc. 86:400-404.

Moyer, C., N.A. Peres, L.E. Datnoff, E.H. Simonne, and Z. Deng. 2008. Evaluation of silicon for managing powdery mildew on gerbera daisy. J. Plant Nutr. 31:2131-2144.
Mueller, D.S., M. Gleason, N.P. Howell, and E.M. Moran. 2008. Evaluation of Griffith Buck roses for resistance to black spot. Hort Technology 18:588-591.

Mynes, J., M. Windham, A. Windham, Y. Li, W. Copes, and J. Spiers. 2007. 'No spray' rose cultivars for the mid-south. Proc. Southern Nursery Assn. Res. Conf. 52:300-303.

Mynes, J., M. Windham, A. Windham, Y. Li, W. Copes, and J. Spiers. 2009. 'No spray' rose cultivars for the mid-south. Proc. Southern Nursery Assn. Res. Conf. 54:83-85.

Seal, D.R. and W. Klassen. 2005. Chilli thrips (castor thrips, assam thrips, yellow tea thrips, strawberry thrips), Scirtothrips dorsalis Hood, provisional management guidelines. Univ. Florida Inst. Food Agr. Sci. ENY-725.

Simonne, E.H. and G.J. Hochmuth. 2010. Soil and fertilizer management for vegetable production in Florida, p. 3-15. In: S.M. Olson and B. Santos (eds.). Vegetable production handbook for Florida 2010-2011. Vance Publishing, Lenexa, KS.

Weeks Roses. 2010. Home Run ${ }^{\circledR}$ roses. 21 July 2010. <http://www.home-runrose.com $/>$.

Wenefrida, I. and J.A. Spencer. 1993. Marssonina rosae variants in Mississippi and their virulence on selected rose cultivars. Plant Dis. 77:246-248.

Whitaker, V.M., S.C. Hokanson, and J. Bradeen. 2007. Distribution of rose black spot (Diplocarpon rosae) genetic diversity in eastern North America using amplified fragment length polymorphism and implications for resistance breeding. J. Amer. Soc. Hort. Sci. 132:534-540.

Wilson, S. and G. Knox. 2006. Landscape performance, flowering and seed viability of 15 japanese silver grass cultivars grown in northern and southern Florida. HortTechnology 16:1-8.

Yokoya, K., K. Kandasamy, S. Walker, Z. Mandegaran, and A.B. Roberts. 2000. Resistance of roses to pathotypes of Diplocarpon rosae. Ann. Appl. Biol. 136:1520.

Zlesak, D.C. 2007. Rose, Rosa $\times$ bybrida, p. 695-740. In: N.O. Anderson (ed.). Flower breeding and genetics: Issues, challenges, and opportunities for the 21 st century. Springer, Dordrecht, The Netherlands. 